\title{
PEMBINAAN KEAGAMAAN \\ PADA KOMUNITAS MUSIK METAL HEAVENHOLIC (Studi Kasus di Heavenholic Bandung)
}

\author{
Azizah Dzikrina, ${ }^{*}$ \\ Udin Supriadi, Agus Fakhruddin \\ Program Studi Ilmu Pendidikan Agama Islam, \\ Fakultas Pendidikan Ilmu Pengetahuan Sosial, Universitas Pendidikan Indonesia \\ *Email: azizahdzikrina@yahoo.com
}

\begin{abstract}
ABSTRAK
Penelitian ini dilatarbelakangi oleh permasalahan yang terjadi di dunia musik metal yang terkenal dengan pergaulan dan gaya hidup bebas tanpa adanya aturan, bebas dalam meminum minuman keras, narkoba, free-sex dan lain sebagainya. Kebebasan tersebut terjadi ketika konser Black Metal sedang berlangsung dan sering membuat kerusuhan. Di Indonesia banyak kasus yang terjadi ketika konser musik metal sedang berlangsung, banyak korban yang terinjak-injak dan nyawa yang melayang sehingga membuat orangtua serta masyarakat khawatir dengan kejadian tersebut dan memandang negatif terhadap musik metal. Dengan adanya kekhawatiran tersebut berdirilah komunitas musik metal Heavenholic.

Penelitian ini bertujuan untuk mengetahui profil, perencanaan, pelaksanaan, hambatan dan hasil dari program komunitas musik metal Heavenholic. Desain penelitian ini menggunakan studi kasus, metode deskriptif dengan pendekatan kualitatif. Pengumpulan data dilakukan melalui observasi, wawancara dan studi dokumen. Perencanaan pembinaan keagamaan dilihat dari jadwal kegiatan komunitas musik metal Heavenholic yang sudah dirancang sebelumnya dan jadwal kegiatan tersebut diimplementasikan ke dalam bentuk pelaksanaan. Adapun pelaksanaan yang ada di komunitas musik metal Heavenholic dilihat dari kegiatan pembinaan keagamaan adalah kajian dan ibadah yaumiyah. Kemudian materi yang

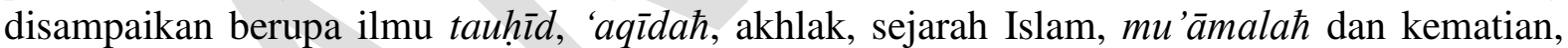
dengan menggunakan metode ceramah, diskusi dan tanya jawab. Hasil dari pembinaan keagamaan di komunitas musik metal Heavenholic cukup berhasil, dilihat dari perubahan sikap para anggota khususnya dalam beribadah, menghasil-kan produk-produk Islami, menggunakan lirik-lirik Islami serta mengandung syiar dakwah. Ilmu yang didapat para anggota harus disampaikan kembali kepada teman-temannya yang berada di cabang komunitas musik metal Heavenholic.
\end{abstract}

Kata Kunci: Pembinaan Keagamaan, Komunitas Musik Metal Heavenholic 


\section{PENDAHULUAN}

Dewasa ini musik merupakan salah satu kebutuhan bagi masyakarat luas dan dari berbagai kalangan, mulai dari anak kecil sampai orang tua. Musik juga salah satu media yang mampu berbicara dalam berbagai bahasa, mampu menyuarakan isi hati para pencipta maupun pendengarnya dan mencerminkan kebudayaan dari berbagai macam belahan dunia. Terdapat banyak macam jenis aliran musik yang ada di belahan dunia, diantaranya Pop, Rock, Jazz, Reggae, Rap, Funk hingga musik Underground (Kisworo, 2012, hal. 42).

Menurut pengamatan peneliti salah satu kalangan yang menyukai musik adalah kalangan remaja, dimana masa remaja merupakan masa mencari jati diri dan memiliki rasa ingin tahu yang begitu besar. Tak sedikit rasa ingin tahu mereka terkadang merugikan bagi mereka sendiri. Hal ini banyak sekali kita temui dalam lingkungan masyarakat, dimana banyak remaja yang kurang kontrol diri dalam pergaulan. Bukan kesuksesan di masa muda yang mereka dapatkan, melainkan kesesatan yang akan diperolehnya.

Adapun fenomena lainnya yang terjadi di kalangan remaja saat ini adalah munculnya musik black metal. Fenomena ini memicu kekhawatiran orang tua bahkan masyarakat. Pandangan masyara- kat yang melihat tingkah laku pada umumnya memandang negatif akan ada-nya musik black metal tersebut (Seng, 2007).

Ann Wan Seng (2007, hal. ix) mengatakan bahwa Isu black metal kembali mendapat perhatian masyarakat ketika kelompok itu masih aktif. Pada tahun baru 2006 tiga ratus remaja telah ditahan dalam sebuah konser yang diselenggara-kan oleh kelompok black metal. Sebelum-nya, sejumlah remaja ditahan karena ter-libat dalam sebuah konser black metal yang diselenggarakan ditempat konser umum di Seramban, Negeri Sembilan, Malaysia.

Hal ini terbukti dengan adanya sebuah tragedi pada tahun 2008 yang masih membekas bagi para musisi underground tanah air. Tragedi yang tak pernah mereka inginkan pun menimpa saat launching album dari band Metalcore asal Bandung, yaitu Beside. Launching yang menjadi duka akibat penumpukan massa di pintu masuk dan mengakibatkan 10 nyawa melayang akibat susah nafas dan terinjakinjak. Band metal Beside ini dianggap sebagai band pembawa maut oleh kalangan masyarakat (Putranto, 2008).

Black metal menjalani cara hidup yang sebebas-bebasnya tanpa batasan dan aturan. Kebebasan yang lewat batas telah menyebabkan banyaknya anggota menjadi liar dan hilang ingatan. Para pengikutnya berpakaian serba hitam dan melaksanakan beberapa upacara rahasia yang bertentangan dengan ajaran agama dan norma masyarakat. Selain menjalani pergaulan dan gaya hidup yang bebas, para pengikut black metal juga terlibat dalam berbagai kegiatan, seperti freeseks, meminum darah kambing, memuja, tengkorak, menggunakan simbol salib terbalik dan sebagainya (Seng, 2007, hal. x).

Pada umumnya kebanyakan para remaja yang mengikuti musik black metal tidak mengetahui apa arti dari musik black metal itu sendiri. Mereka hanya mengikuti musik black metal tanpa mengetahui apa arti yang sebenarnya. Ann Wan Seng (2007, hal. xi) mengatakan bahwa aliran musik black metal itu menyesatkan dan menjerumuskan para remaja ke dalam lembah keruntuhan akhlak dan moral yang serius.

Bukan hanya black metal saja, keprihatinan khusus juga muncul akhirakhir ini di daerah dengan penduduk berpendapatan rendah yaitu meningkatnya kekerasan geng, yang tergolong dalam tingkatan yang lebih berbahaya daripada sebelumnya. Pisau dan alat pemukul telah digantikan oleh granat dan senjata otomatis, biasanya dibeli dengan uang yang diperoleh dari menjual obat terlarang. Ikatan antara anggota geng sangatlah kuat, terutama bagi anak-anak atau remaja yang hubungannya terputus dengan keluarga, sekolah, pekerjaan dan 
masyarakat. Anak-anak pada usia antara sembilan sampai sepuluh tahun sudah ikut bergabung dengan geng di lingkung- lan sekitar tempat tinggalnya walaupun belum menjadi anggota, mereka memiliki keinginan untuk membuktikan bahwa mereka cukup berharga untuk dijadikan anggota geng pada usia 12 tahun (Santrock, 2003).

Kenalan remaja di atas tidak terjadi begitu saja, tentu banyak hal yang menyebabkan terjadinya kenakalan pada remaja tersebut. Sofyan Willis (2010, hal. 88) mengatakan bahwa "kenakalan anak dan remaja itu disebabkan kegagalan mereka dalam memperoleh penghargaan dari masyarakat tempat mereka tinggal. Penghargaan yang mereka harapkan ialah tugas dan tanggung jawab seperti orang dewasa. Tetapi orang dewasa tidak dapat memberikan tanggung jawab dan peranan itu, karena belum adanya rasa kepercayaan terhadap mereka."

Selain di lingkungan masyarakat, kenakalan bisa disebabkan dari keluarga itu sendiri dan peranan orang tua dalam mendidik anaknya. Faktor yang menyebabkan terjadinya kenalan remaja tersebut diantaranya, anak kurang kasih sayang dan perhatian orang tua, lemahnya keadaan ekonomi orang tua, keluarga yang tidak harmonis dan kurangnya pendidikan yang diberikan oleh orang tua maupun keluarganya (Willis, 2010, hal. 99).

Dalam pandangan Islam, anak adalah amanah dari Allāh. Oleh karena itu, dalam konteks pendidikan orang tua harus menjaganya secara penuh. Orang tua harus mampu mengantarkan dan memengenalkan anaknya kepada Allāh. Orang tua harus bertanggung jawab menyelamatkan diri dan keluarganya melalui pendidikan Islam (Mahmud, dkk, 2013, hal. 142).

Adapun perkembangan kenalankenakalan di kalangan remaja memang sangat mengerikan. Bahkan perkembangan musik black metal di Indonesia semakin merambah dan menarik perhati- an khususnya bagi para remaja untuk me- ngikuti musik black metal yang beraliran metal underground. Namun, berbeda dengan komunitas Havenholic mereka ingin kembali ke jalan yang lurus dan ingin mempelajari kembali nilai-nilai ajaran agama Islam yang sudah mereka tinggalkan. Sebagaimana Allāh telah menjelaskan dalam Q.S. al-Fātiḥah [1]: 6-7 yang berbunyi :

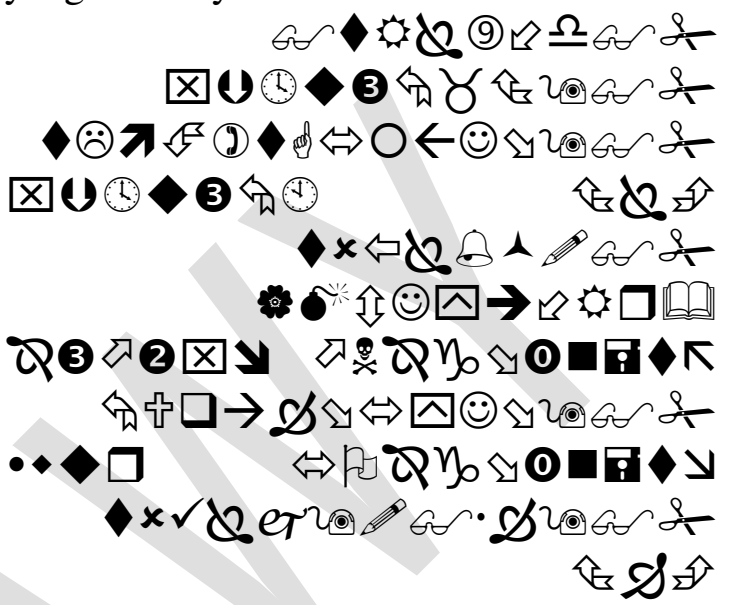

Artinya : “(6)Tunjukilah Kami jalan yang lurus. (7) Yaitu jalan orang-orang yang telah Engkau anugerahkan ni'mat kepada mereka, bukan (jalan) mereka yang dimurkai (orang-orang yang mengetahui kebenaran dan meninggalkannya) dan bukan (pula jalan) mereka yang sesat (orang-orang yang meninggalkan kebeneran, karena ketidaktahuan dan kejahilan”. (Qs. al-Fātiḥah [1] : 6)

Dengan demikian, pada Q.S. alFātiḥah (1): 6 di atas menjelaskan tentang

Permohonan agar Allāh menganugrahkan kepada si pemohon dengan melalui naluri, panca indra, akal dan agama ke- mampuan untuk menggapai jalan yang lurus. Sehingga makna "aș-Sirațal Mus- taqìm" tidak saja dilihat dari naluri mau- pun panca indera lainnya, akan tetapi dibenarkan oleh akal serta dari saat ke saat untuk memperoleh bimbingan dan pengetahuan yang bersumber dari Allāh kemudian diberi pula kemampuan untuk melaksanakannya (Shihab, 2009, hal. 7879).

Sedangkan Q.S. al-Fātiḥah (1) : 7 menjelaskan bahwa arti dari "tunjukkanlah kepada kami jalan yang lurus" ialah 
jalan orang-orang yang telah Engkau berikan nikmat kepadanya. Yaitu mereka yang memperoleh hidayah, istiqamah dan ketaatan kepada Allāh dan Rasūl-Nya, serta mengerjakan perintah-Nya dan meninggalkan larangan-Nya. Bukan jalan orang-orang yang murka meskipun mereka mengetahui kebenarannya, namun menyimpang darinya. Bukan juga orangorang yang sesat, yaitu orang-orang yang tidak mengetahui ilmu pengetahuan, sehingga mereka berada dalam kesesatan dan tidak mendapatkan jalan menuju kebenaran (Syaikh, 2009, hal. 35).

Secara kodratnya, memang setiap manusia menginginkan suatu kebahagiaan. Ada berbagai cara yang bisa ditempuh oleh setiap orang untuk memperoleh kebahagiaan tersebut. Seperti halnya para penikmat musik black metal, mereka mendapat kebahagiaan melalui musik tersebut. Begitu pun dengan komunitas Heavenholic, yang sempat merasakannya. Mereka terjerumus ke dalam kesesatan melalui musik-musik black metal. Namun kenikmatan tersebut hanya bersifat sementara dan menyesatkan. Berkat petunjuk dari-Nya, kini komunitas Heavenholic lambat laun kembali kepada jalan yang benar.

Sejalan dengan pendapat yang peneliti kemukakan di atas, maka peneliti mengadakan pra penelitian kepada komunitas Heavenholic. Mereka menjelaskan bahwa komunitas Heavenholic merupakan perkumpulan orang-orang yang menyukai musik black metal beraliran underground, dimana orang-orangnya jauh dari ajaran agama Islam. Mereka hanya mengenal musik keras, narkoba, freeseks dan sebagainya yang jauh dari ajaran agama Islam. Oleh karena itu, salah satu diantara mereka menyadari bahwa perbuatan tersebut sudah me-langgar ajaran agama Islam dan mereka ingin kembali ke jalan yang benar tanpa dipandang negatif oleh masyarakat sekitar maka terbentuklah komunitas Heavenholic yang di bawah bimbingan Remaja
Aktivis Masjid Pusdai (RAMPAI Pusdai) Bandung, Jawa Barat.

Oleh karena itu, penggemar musik tersebut harus mendapatkan pembinaan keagamaan dengan baik meskipun mereka senang dengan musik tersebut, tetapi mereka harus membatasi akhlak sehingga tidak terkena dampak negatif-nya. Inilah pentingnya pembinaan ke-agamaan bagi komunitas Heavenholic yang bertujuan untuk mempelajari ajaran-ajaran agama Islam dan untuk beribadah serta mendekatkan diri kepada Allāh.

Pembinaan keagamaan yang ada di komunitas Heavenholic itu sendiri tidak akan meninggalkan musik Black Metal aliran underground. Musik tersebut dijadikan sebagai media dakwah dan membawa orang-orang yang mengikuti Black Metal aliran underground untuk kembali ke jalan yang lurus dengan cara mengubah lirik musiknya ke dalam lirik nuansa islami namun tetap dengan aliran musik underground nya.

Maka berdasarkan pada uraian dari latar belakang masalah tersebut, peneliti tertarik untuk mengetahui bagaimana pembinaan keagamaan yang diterapkan pada komunitas Heavenholic di Bandung, melalui penelitian dengan judul "Pembinaan Keagamaan Pada Komunitas Musik Metal Heavenholic (Studi kasus di Heavenholic Bandung)".

\section{METODE}

Dalam penelitian ini, peneliti menggunakan desain penelitian studi kasus. Studi kasus adalah suatu pendekatan untuk mempelajari, menerangkan atau menginterpretasikan suatu kasus dalam konteksnya secara natural tanpa adanya intervensi pihak luar. Penelitian studi kasus juga merupakan studi yang mendalam mengenai unit sosial tertentu dan hasil dari penelitian tersebut dapat memberikan gambaran luas serta mendalam. Tujuan dari studi kasus adalah untuk mempelajari secara intensif tentang latar belakang keadaan sekarang dan interaksi 
lingkungan sesuatu unit sosial, seperti individu, kelompok, lembaga atau masyarakat (Suryabrata, 2012, hal. 80).

Dalam desain ini, peneliti menggunakan pendekatan kualitatif. Pendekatan kualitatif adalah metode penelitian yang digunakan untuk meneliti pada obyek yang alamiah atau sebagai lawan-nya adalah eksperimen dimana peneliti sebagai instrumen kunci, teknik pe-ngumpulan data dilakukan secara tri-angulasi (gabungan), analisis data bersifat induktif dan hasil penelitian kualitatif menekankan makna dari pada genera-lisasi (Sugiono, 2009, hal. 1).

Penelitian ini dilaksanakan disebuah Komunitas yang bernama Heavenholic tepatnya di Pusdai Kota Bandung yang beralamat di J1. Diponegoro, No. 63 Bandung, Jawa Barat 40133, Indonesia. yang menjadi subjek pada penelitian ini adalah orang-orang yang mengerti dan terlibat dengan segala aktivitas dari program kegiatan di komunitas musik metal Heavenholic. Selain itu, mereka harus memahami serta mengetahui latar belakang adanya program kegiatan di komunitas musik metal Heavenholic. Yang termasuk subjek pada penelitian ini adalah ketua komunitas, pengurus komu-nitas, anggota dan masyarakat yang me-ngikuti kegiatan dari program komunitas musik metal Heavenholic Bandung.

Teknik pengumpulan data merupakan langkah yang paling utama dalam penelitian, karena tujuan utama dari penelitian adalah mendapatkan data. Oleh karena itu, dalam data penelitian kualitatif diperoleh dari sumber data dengan menggunakan teknik pengumpulan data yang dapat dikelompokkan menjadi empat, diantaranya adalah wawancara, observasi, dokumentasi dan triangulasi.

Data yang sudah didapat melalui teknik pengumpulan tersebut, langkah selanjutnya adalah dengan menganalisis data. Dari data tersebut dianalisis dengan mereduksi data dengan cara memilih data yang dibutuhkan, setelah itu dikategorisasikan dengan menggunakan koding.
Data yang sudah direduksi lalu disajikan dalam display data dengan uraian singkat secara deskriptif dan setelah semuanya selesai tahap selanjutnya adalah menyimpulkan (verification).

\section{HASIL DAN PEMBAHASAN}

\section{Profil Komunitas}

Pada tahun 2012 terbentuk komunitas musik metal Heavenholic secara resmi, komunitas ini terbentuk di Masjid Pusdai Bandung yang berada di alamat Jl. Diponegoro No.63 Bandung dan berada di bawah bimbingan Remaja Masjid Pusdai Bandung.

Para pendiri komunitas ini berjumlah lima orang, yaitu Kang Yadi (sebagai ketua komunitas), Kang Adi, Kang Rudi, Kang Seftian, al-Bukhārī Muslim (Bu Chek). Anggota yang ada di komunitas ini berjumlah mencapai 200-250, pe-ngurus inti berjumlah 20-25 orang.

Dasar pemikiran pada komunitas musik metal Heavenholic yang pertama adalah lebih kepada keinginan untuk merubah kepribadian pada diri masingmasing menjadi lebih baik dan lebih di Riḍāi oleh Allah Swt.

Kedua, dibentuknya komunitas ini sangat sederhana sekali yaitu ingin mengembalikan sisi positif terhadap musik khususnya musik metal, fashion dan clothing agar anak-anak muda tidak mengikuti hal-hal yang negatif terhadap musik, fashion dan clothing.

Dasar pemikiran pembentukan komunitas musik metal Heavenholic ter-dapat pada Q.S. al-Așr [103] : 1-3 yang berbunyi:

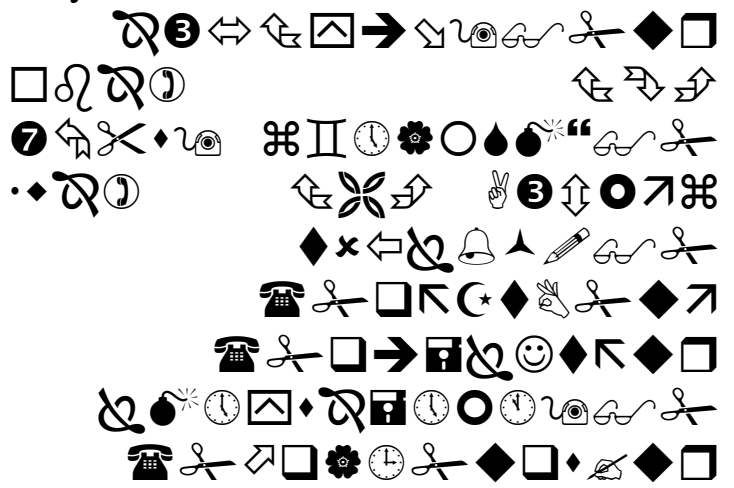




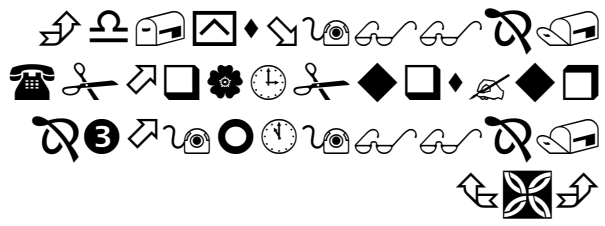

"Demi masa. Sesungguhnya manusia itu benar-benar dalam kerugian, kecuali orang-orang yang beriman dan mengerjakan amal saleh dan nasehat menasehati supaya mentaati kebenaran dan nasehat menasehati supaya menetapi kesabaran."

Visi, pertama, membangun potensipotensi yang kemandirian, bersosial dan bekerja berlandasakan pada pemikiranpemikiran Islam dan kedua, mengajak anak-anak muda untuk kembali ke arah yang lebih baik. Misi, pertama, dengan memakai alat yang disukai oleh anak-anak muda sekarang dan kedua, me-ngajaknya untuk berbincang-bincang ke-pada hal-hal yang positif.

\section{Perencanaan}

Perencanaan yang ada di komunitas musik metal Heavenholic terbagi menjadi tiga bagian, yaitu: a. program mingguan adalah program yang dilaksanakan pada hari Senin dan Jumat, akan tetapi kegiatan yang dilaksanakan pada hari Senin tidak berjalan sesuai dengan rencana karena kesibukan masing-masing pendiri, pengurus maupun anggotanya. Sedangkan kegiatan yang dilaksanakan pada hari Jumat sudah berjalan sesuai dengan rencana. Adanya kajian hari Jumat di-rencanakan pada tahun 2012 bertepatan dengan berdirinya komunitas ini dengan menggunakan metode diskusi dan ceramah b. Program bulanan adalah program yang dilaksanakan sebulan sekali dengan mengundang seorang ustaż untuk hadir mengisi ceramah kepada pengurus maupun anggota komunitas musik metal Heavenholic. Perencanaan kedepannya program ini akan dilaksanakan pada minggu ketiga setiap bulannya dan menghadirkan salah satu seorang ustaż yang tetap dan akan menjadi murabbī di komunitas tersebut c. Program tahunan adalah program yang dilaksana- kan setiap satu tahun sekali, program tahunan tersebut meliputi konser metal atau hard-core. Perencanaan dilakukan sebelum konser diselenggarakan. d. Program gabungan adalah program kegiatan yang ikut bergabung bersama organisasi RAMPAI, program yang ada di RAMPAI sudah menjadi bagian dari program di komun-itas musik metal Heavenholic karena komunitas ini berada dibawah naungan RAMPAI.

\section{Pelaksanaan}

Pelaksanaan program pembinaan keagamaan yang dilaksanakan oleh komunitas musik metal Heavenholic adalah lebih kepada kegiatan kajian rutin yang dilaksanakan setiap hari Jumat setelah se-

lesai shalat 'Isyā. Adapun kajian yang dilaksanakan pada minggu ketiga setiap bulannya mengundang salah satu seorang ustaż sebagai murabbī komunitas tersebut dan yang terakhir pembinaan keagamaan di Heavenholic yaitu kegiatan ibadah yaumiyah berupa ibadah sunnah yang dilakukan setiap hari.

Hal tersebut sesuai dengan teori yang dikemukakan oleh Gafur (1978, hal. 7) bahwa pembinaan atau pe-ngembangan adalah upaya pendidikan baik secara formal maupun non formal yang dilaksanakan secara sadar, terarah, teratur dan bertanggung jawab dalam rangka membimbing dan mengembangkan suatu dasar-dasar kepribadian yang seimbang, utuh dan selaras untuk mengembangkan dirinya kearah pribadi yang mandiri.

Berdasarkan dari penjelasan di atas bahwa pelaksanaan kegiatan kajian yang dilakukan oleh komunitas musik metal Heavenholic telah dilaksanakan secara terarah dan teratur. Hal tersebut telah dibuktikan pada program mingguan dan bulanan yang dilakukan sesuai jadwal yang sudah ditetapkan dan teroganisir dengan baik, mulai dari persiapan hingga akhir kegiatan.

Sedangkan dalam pelaksanaan ibadah yaumiyah dilaksanakan setiap hari selama satu minggu, ibadah tersebut meliputi 
shalat tahajud, shalat ḍuhā, membaca alQurān, puasa sunnah dan lain sebagainya. Sesuai dengan arti dari pembinaan di-mana dalam pembinaan tersebut, sese-orang tidak hanya dibantu untuk mem-peroleh pengetahuan saja, akan tetapi bagaimana pengetahuan tersebut dilak-sanakan dan dipakai dalam kehidupan sehari-hari (Syafa'at, dkk, 2008, hal. 153).

Namun demikian dalam pelaksanaan kegiatan ibadah yaumiyah belum berjalan dengan maksimal karena pelaksanaan kegiatan tersebut belum dilaksanakan oleh seluruh anggota komunitas musik metal Heavenholic dan program kegiatan ini merupakan program baru dari pem-binaan keagaman di komunitas musik metal Heavenholic, hanya sebagian dari mereka yang melaksanakan kegiatan ibadah yaumiyah, seperti pendiri dan pe-ngurus komunitas musik metal Heaven-holic.

Pembinaan keagamaan di komunitas musik metal Heavenholic tidak terlepas dari materi dan metode pembinaan. Materi pembinaan menurut Basyīr (dalam Rahmawati, 2001, hal. 12) adalah ajaran agama Islam yang terkandung dalam alQurān dan Hadīis yang meliputi berbagai aspek, yakni aspek 'aqīda, ibadah, akhlak dan mu'āmalaћ.

Senada dengan pengertian di atas, berdasarkan hasil observasi kegiatan kajian yang ada di komunitas musik metal Heavenholic menjelaskan bahwa materi yang disampaikan oleh pemateri di komunitas musik metal Heavenholic meliputi aspek-aspek tersebut, diantaranya adalah ilmu tauhid, aqìdaћ, akhlak, sejarah

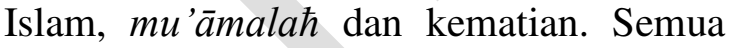
materi yang diberikan setiap pembinaan keagamaan baik pada program mingguan yang dilaksanakan hari Jumat dan program bulanan yang mengundang seorang ustaż sebagai murabbī.

Metode yang selalu digunakan oleh komunitas musik metal Heavenholic pada saat kajian yang dilakukan setiap hari Jumat adalah ceramah, diskusi dan tanya jawab. Sejalan dengan Amin (2010, hal. 69) dan Arifin (1982, hal. 70) menjelas- kan bahwa para pembina atau pembimbing yang ada di komunitas tersebut memerlukan beberapa metode yang dapat dilakukan dalam sebuah tugas pembinaan keagamaan atau yang biasanya disebut dengan tugas bimbingan serta konseling, salah satunya adalah metode wawancara, Group Guidance (Bimbingan Kelompok) dan Metode Direktif (metode yang bersifat mengarahkan atau arahan).

Berdasarkan hasil observasi yang dilakukan oleh peneliti bahwa metode yang berada di komunitas musik metal Heavenholic menggunakan metode wawancara, Group Guidance (Bimbingan Kelompok) dan metode direktif.

Dengan demikian dapat disimpulkan bahwa secara keseluruhan program pembinaan keagamaan sudah cukup sesuai dengan apa yang telah direncanakan, namun program kegiatan ibadah yaumiyah belum sesuai karena program tersebut program baru dari komunitas musik metal Heavenholic. Terlihat dengan adanya jadwal kegiatan pembinaan keagamaan yang diimplementasikan dalam pelaksanaan sebagaimana observasi langsung yang peniliti lakukan dalam setiap kegiatan pembinaan keagamaan di komunitas musik metal Heavenholic.

4. Hambatan

Pada program mingguan yang dilaksanakan pada hari Senin sebelumnya membahas tentang buku apa yang mau dikaji, akantetapi program pada hari tersebut tidak berjalan sesuai dengan rencana karena anggota yang datang pada hari Senin sedikit hanya dua orang, jadi program tersebut dialihkan menjadi hari Jumat saja seperti biasanya. Kurangnya SDM (Sumber Daya Manusia) untuk acara atau kegiatan yang akan dilaksana-kan. Waktu yang tidak sesuai dengan anak-anak yang lainnya karena kesibukan mereka masing-masing.

Pengaruh dari luar karena ketika pendiri atau para pengurus komunitas mengislamisasi dan mengajak mereka untuk mengikuti kegiatan di komunitas ini mereka berubah dengan cepat, seperti 
melaksanakan ibadah, akan tetapi ketika mereka berkumpul kembali dengan anakanak musik lainnya atau yang ada di luar lingkungan Heavenholic mereka terkadang diajak kembali untuk berbuat maksiat. Mayoritas anak-anak muda yang menyukai musik metal, kemudian bergabung dengan Heavenholic kurang dalam pendidikan agama Islam di-keluarganya. Ada-nya sifat malas pada anggota ketika ada kegiatan pembinaan keagamaan di komu-nitas musik metal Heavenholic. Kurang-nya komunikasi antar anggota maupun pengurus. Banyak yang mencela sesama teman penyuka musik yang belum sadar. Kekhawatiran orang tua karena kegiatan pembinaan keagamaan di Heavenholic dilaksanakan pada malam hari setelah selesai shalat Isya. Orang tua dan lingkungan rumah memandang negatif pada perkumpulan-perkumpulan tersebut karena sebelumnya ada isu tentang teroris.

Dipandang sebelah mata oleh masyarakat karena merasa aneh dengan tampilan yang memakai baju serba hitam, memakai anting dan bertato memasuki masjid, sebaliknya ketika berada di dalam masjid mereka juga dipandang sebelah mata dengan tampilan mereka.

Solusi yang dilakukan diantaranya adalah dengan jalan terus, berdakwah, memberikan obrolan-obrolan yang positif lewat diskusi atau sharing, memberikan semangat dan memotivasi kepada anakanak dengan mengatakan "ini adalah tantangan, ini sudah menjadi fitrah setiap orang yang ingin berubah, Allāh senantiasa melihat niat kita". Dengan adanya masalah yang dihadapi dapat menemukan pemecahan masalah dan menemukan kunci-kunci syiar atau dakwah, kunci-kunci kalimat yang bisa diterima oleh anak-anak. Masalah adalah nikmat dan harus disyukuri, jadi jika tidak diberi masalah, maka tidak diberi ilmu sama Allāh.

Setelah melihat solusi dari adanya hambatan yang telah dijelaskan oleh pendiri, pengurus dan anggota komunitas musik metal Heavenholic dapat disimpul- kan bahwa pembinaan keagamaan berjalan cukup lancar meskipun setiap pelaksanaan semua kegiatan di komunitas musik metal Heavenholic terutama dalam pelaksanaan kegiatan kajian hanya sedikit yang hadir, hal tersebut tidak menjadi masalah yang besar karena kegiatan tetap berjalan dengan lancar. Akan tetapi berdasarkan hasil wawancara dan observasi langsung yang dilakukan oleh peneliti dapat disimpulkan bahwa pihak komunitas musik metal Heaven-holic sudah berusaha dengan sebaik mungkin untuk menghadapi faktor-faktor penghambat tersebut.

\section{Hasil}

Manfaat dari pelaksanaan program pembinaan keagamaan di komunitas musik metal Heavenholic sebagaimana hasil wawancara dengan pendiri dan pe-ngurus bahwa dengan diadakannya pem-binaan keagamaan akan memberikan manfaat sesuai dengan individu mereka masingmasing yaitu kembali kepada niat awal mereka. Niat awal mereka adalah ingin mengubah musik ke arah yang positif, tidak ada lagi kelalaian dalam beribadah, menumbuhkan sikap kritis ter-hadap suatu hal, saling mengingatkan satu sama lain, dan membangun satu keluarga besar yang disatukan atau didekatkan karena pemikiran-pemikiran yang sama terhadap agama Islam se-hingga dapat menimbulkan rasa nyaman.

Hasil dari pembinaan keagamaan pada anggota juga tidak hanya sekedar dilihat dari perubahan pada diri sendiri saja, akan tetapi komunitas ini dapat menghasilkan sebuah karya islami, seperti menyablon, clothing dengan gambar, tulisan dan bertemakan yang mengajak kepada kebaikan.

Hasil dari pembinaan keagamaan yang telah dicapai oleh band metal dari komunitas musik metal Heavenholic adalah sebuah lirik lagu yang mengajarkan kepada kebaikan dan mengandung syiar-syiar dakwahnya, hal tersebut sesuai dengan observasi konser hardcore yang telah peneliti lakukan. 
Senada dengan Syaikh Muhammad bin Jamīl Zainu (dalam Jawas, 2009, hal. 73-75) menjelaskan bahwa nyanyian yang dibolehkan diantaranya adalah sebagai berikut: 1) Nyanyian (syair) islami pada saat bekerja yang dapat membantu menumbuhkan semangat, terlebih lagi bila di dalamnya terdapat doa, 2) Nyanyian yang berisikan ajakan mentauhidkan kepada Allāh Swt., mencintai Rasūl Allāh Saw. menganjurkan jihad fì sabīlillāh, mengkokohkan akhlak atau mengajak untuk saling mencintai dan tolong menolong sesama muslim atau menyebutkan kebaikan-kebaikan Islam.

Hal ini peneliti sejalan dengan pendapat Syaikh Muhammad bin Jamīl Zainu yang menghalalkan atau membolehkan musik dan nyanyian karena lirik lagu yang disampaikan oleh komunitas tersebu sudah sesuai dengan ajaran-ajaran Islam dan sependapat dengan pengertian dakwah yang sudah dijelaskan di atas. Hal tersebut salah satu cara untuk ber-dakwah kepada anak-anak yang me-nyukai musik metal karena berdakwah bisa dilakukan kepada siapa saja dan di-lakukan dengan cara apapun yang sesuai dengan jalan Allāh.

Dengan adanya kegiatan kajian yang dilaksanakan setiap hari Jumat para pendiri, pengurus dan dikhususkan bagi setiap anggota Heavenholic untuk menyampaikan ilmu agama yang telah mereka dapatkan dari kajian tersebut kepada teman-temannya di luar komunitas musik metal Heavenholic, cabang dari Heavenholic yang ada di daerahnya masing-masing dan komunitas ini juga mempunyai desa binaan yang berada di daerah Cicalengka dengan kegiatan membina keagamaan pada anak-anak muda yang ada di desa tersebut. Dari hasil kegiatan kajian tersebut menghasilkan pembinaan keagamaan dan dakwah.

\section{KESIMPULAN}

Berdasarkan uraian di atas, maka dapat disimpulkan bahwa secara ke- seluruhan pembinaan keagamaan di komunitas musik metal Heavenholic cukup baik, dilihat dari segi perencanaan, pelaksanaan dan hasil. Namun, evaluasi di komunitas musik metal Heavenholic belum cukup baik karena komunitas ini tidak seperti organisasi yang ditulis secara terstruktur dan komunitas ini termasuk ke dalam organisasi informal yang tidak terikat oleh apapun karena komunitas mempunyai kebebasan untuk berkreasi dan mengembangkan kreatifitasnya masingmasing. Kesimpulan yang ter-dapat pada pembinaan keagamaan di komunitas musik metal Heavenholic Bandung secara terperinci adalah sebagai berikut:

Komunitas musik metal Heavenholic secara resmi berdiri pada tahun 2012 yang didirikan oleh lima orang pendiri, yaitu kang Yadi, kang Adi, kang Rudi, kang Septian dan kang Bukhārī Muslim. Komunitas ini terbentuk di masjid Pusdai Bandung yang beralamat-kan di Jl. Diponegoro No. 63 Bandung dan berada di bawah bimbingan Remaja Aktivis Masjid Pusdai (RAMPAI). Dasar pe-mikiran yang ada di komunitas ini adalah ingin mengubah kepribadian masing-masing menjadi lebih baik yang di Riḍā oleh Allāh dan ingin mengembalikan sisi positif terhadap musik khususnya musik metal, fashion dan clothing. Sedangkan tujuan adanya program pembinaan ke-agamaan pada komunitas musik metal Heavenholic adalah pertama, mencipta-kan suatu tempat (wadah) dan berperan sebagai jembatan yang menghubungkan antara musik dan masjid. Kedua, meng-islamisasi budaya-budaya dari luar dan ketiga, berapresiasi terhadap pemikiran Islam apapun itu, terutama dalam musik metal. Visi dari komunitas ini adalah membangun potensi-potensi kemandirian, bersosial serta bekerja berlandaskan pada pemikiran Islam dan mengajak anak-anak muda untuk kembali ke arah yang lebih baik. Sedangkan misinya adalah dengan memakai alat yang disukai oleh anak-anak muda sekarang dan berdiskusi kepada halhal yang positif. 
Program yang ada di komunitas musik metal Heavenholic terbagi menjadi tiga bagian, yaitu program mingguan, bulanan dan tahunan. Program mingguan tersebut dilaksanakan setiap hari Jumat dengan kegiatan kajian, kegiatan kajian dilaksanakan setelah selesai shalat 'Isyā sampai pukul 21.00 atau sampai selesai. Program bulanan yaitu program kerja yang dilaksanakan pada minggu ketiga setiap bulannya dengan mengundang se-orang ustaż untuk hadir mengisi ceramah dan ustaż tersebut sudah menjadi murabbi di komunitas musik metal Heavenholic. Program tahunan meliputi kegiatan mabit dan konser metal atau hardcore dengan mengambil tema mengenai perlawanan terhadap zionisme, Palestina, Religius dan sebagainya. Pihak yang terlibat pada semua program adalah pendiri, pengurus, anggota dan pihak luar boleh mengikuti kegiatan-kegiatan tersebut.

Program pembinaan keagamaan yang ada di komunitas musik metal Heavenholic lebih kepada program mingguan, bulanan dan ibadah yaumiyah. Pada program mingguan dan bulanan diadakannya kegiatan kajian rutin, materi yang disampaikan dalam kajian setiap hari Jumat mengenai ilmu tauhīd, 'aqīdah, akhlak, sejarah Islam, mu'āmalaћ dan kematian. Sedangkan untuk metode yang biasa digunakan dalam kajian setiap mingguan dan bulanan adalah metode ceramah, diskusi dan tanya jawab. Untuk kegiatan ibadah yaumiyah berupa ibadah sunnah yang dilakukan setiap hari, misalnya shalat tahajud, puasa sunnah dan ibadah lainnya.

Beberapa faktor yang menjadi penghambat salah satunya adalah kurangnya SDM, program mingguan yang dilaksanakan setiap hari senin tidak berjalan lagi, waktu yang tidak sesuai dengan anakanak, adanya sifat malas yang ada pada diri masing-masing anggota, kurangnya komunikasi antar sesama anggota mau-pun pengurus, banyak yang mencela se-sama teman penyuka musik yang belum sadar, kekhawatiran orang tua, orang tua serta lingkungan rumah memandang ne-gatif dengan komunitas tersebut dan dipandang sebelah mata oleh masyarakat.

Solusi yang dilakukan diantaranya adalah dengan jalan terus, berdakwah, memberikan obrolan-obrolan yang positif lewat diskusi atau sharing, memberikan semangat serta memotivasi kepada anakanak atau seluruh anggota komunitas, mengoptimalkan komunikasi dengan seluruh pendiri, pengurus maupun anggotanya dan memberi tahu kepada orangtua serta lingkungan disekitar rumah secara bertahap dan menggunakan metode yang menarik agar mereka tidak berprasangka buruk atau berfikiran negatif lagi tentang perkumpulan yang ada di komunitas musik metal Heavenholic.

Hasil program pembinaan keagamaan di komunitas musik metal Heavenholic perubahan pada diri sendiri, meninggalkan hal-hal yang negatif, mengubah musik metal ke arah yang positif, sebuah lirik lagu yang mengajarkan kepada ke-baikan atau lebih mengarahkan ke arah yang positif dan mengandung syiar-syiar dakwahnya, mempunyai desa binaan di daerah Cicalengka dengan kegiatan membina keagamaan pada anak-anak muda yang berada di desa tersebut. Adapun evaluasi yang dilakukan oleh komunitas musik metal Heavenholic lebih kepada amal sholeh, seperti halnya menyadarkan individu masing-masing dalam hal kebaikan.

\section{REFERENSI}

Depok: Al-Huda.

(2005). Al-Qur'an.

Amin, S. M. (2010). Bimbingan dan Konseling Islam. Jakarta: Amzah.

Arifin, M. (1982). Pedoman Pelaksanaan Bimbingan dan Penyuluhan Agama. Jakarta: Golden Terayon.

Gafur, A. (1978). Pola Dasar Pembinaan dan Pengembangan Generasi Muda. Jakarta: Sekretariat Menteri Muda 
Urusan Pemuda Departemen Pendidikan dan Kebudayaan.

Jawas, Y. b. (2009). Hukum Lagu,Musik dan Nasyid. Bogor: Pustaka AtTaqwa.

Kisworo, S. (2012). Perancangan Komunikasi Visual Sebagai Media Promosi Album Kedua Band Blasphemy Doom Black Metal "Lelembut". Canthing Akademi Seni dan Desain Indonesia Surakarta, 42-43.

Mahmud, dkk. (2013). Pendidikan Agama Islam Dalam Keluarga: Sebuah Panduan Lengkap bagi Para Guru, Orang Tua dan Calon. Jakarta: Akademia.

Putranto, W. (2008, Februari 11). Journal Of a Rock. Dipetik Februari 17, 2015, dari Journal Of a Rock Web site:

http://www.wenzrawk1.blogspot.co $\mathrm{m}$

Rachmawati, Y. (2005). Musik Sebagai Pembentuk Budi Pekerti. Yogyakarta: Jalasutra.

Santrock, J. W. (2003). Adolescence Perkembangan Remaja. (S. B. Adelar, \& S. Saragih, Penerj.) Jakarta: Erlangga.

Seng, A. W. (2007). Membongkar Kesesatan Black Metal. Bandung: MQ Publishing.

Shihab, Q. (2009). Tafsir al-Misbah : Pesan, Kesan dan Keserasian alQur'an . Jakarta: Lentera Hati.

Sugiono. (2009). Memahami Penelitian Kualitatif. Bandung: Alfabeta.

Suryabrata, S. (2012). Metodologi Penelitian. Jakarta: Rajawali Pers.

Syafa'at, dkk. (2008). Peranan Pendidikan Agama Islam Dalam Mencegah
Kenakalan Remaja. Jakarta: Rajawali Pers.

Syaikh, A. b. (2009). Tafsir Ibnu Katsir Jilid 1. (Y. Harun, H. N. Wahid, F. A. Okbah, Y. A. Qadir Jawas, M. Bamu'allim, F. Dloifur, et al., Penyunt., \& A. Ghofar, Penerj.) Pustaka Asy-Syafi'i.

Willis, S. (2010). Remaja dan Masalahnya. Bandung: Alfabeta. 